of external origin. I also noted similar oral pigmentation from this drug and confirmed that hand pigment could be produced by drug plus saliva. When breaking a $50-\mathrm{mg}$ tablet it was uncommon to get a clean break and I therefore attempted to obtain a proper half and kept it for a later dose; the first crumbled half was ingested by lifting the main portion with right thumb and index finger and the remainder by licking it off the palm. The occasional pigment on the fingers was presumably due to saliva in contact with powdered drug under the nails.

In Dr. Silverton's case the absence of pigment on the left middle finger may possibly be explained by the fact that it was simply in contact with the dry surface of an unbroken tablet.

It seems probable that pigmentation from phenindione is produced by combined contact of alkali and the drug. This would explain the pigmentation on the hands and in the mouth, and its more common appear- ance with the use of broken tablets, permitting easier combination of alkaline solution with powdered drug. It may also be relevan to urinary pigment, which is often spasmodic and may again depend on alkalinity. The skin pigment can be removed by prompt washing, but even after drying some minor degree can be reproduced by further application of saliva.

If not promptly removed the pigment can be quite adherent and embarrassing.

It is interesting to speculate about the possibility of this alkaline-drug combination as a factor in the more serious drug reaction to phenindione, including rashes, pyrexia, neutropenia, and liver and renal damage.

This contact pigmentation could be reduced or eliminated, and at the same time a more accurate dosage ensured by the use of the 25-mg. tablet.-I am, etc.,

\section{Belfast City Hospital,}

\section{J. JEFFERSON.} Belfast 9.

\title{
Chloroquine Psychosis
}

SIR,-Chloroquine has been used in the treatment of discoid lupus erythematosus following the successful use of quinacrine by Prokoptchouk $^{1}$ in 1940 in Russia, and in England by Page ${ }^{2}$ in 1951.

Unfortunately it has become clear that there are many undesirable side-effects associated with the antimalarials. Among them are anorexia and nausea, skin eruptions of many types, including a lichenoid reaction, pigmentary changes (especially bleaching of hair), aplastic anaemia, chronic porphyria, and corneal opacity and retinopathy. ${ }^{3}$ Toxic psychosis, depression, and polyneuritis have been reported usually due to mepacrine. Sapp 4 reports a case due to chloroquine, and refers to reports of five other patients who developed mental disturbance while taking chloroquine.

The purpose of this communication is to report a further case of this complication of chloroquine treatment.

The patient, a man of 59 years, was attending the Skin Hospital for treatment of a patch of atrophic alopecia on the vertex of the scalp. This was 4 in. $(10 \mathrm{~cm}$.) in diameter, and had gradually reached that size since the onset eight years previously. There were pustules at the periphery of the lesion. This was diagnosed as folliculitis decalvans. 5 Because of the lack of response to antibiotics and local steroid therapy, and the resemblance of this condition to discoid lupus erythematosus of the scalp, treatment was started with chloroquine, 250 mg. b.d. He took the tablets for three weeks without ill-effect, then he was sick one morning and felt mentally depressed. He continued in his work as a security officer at a power station, but it was found that he was completing his report sheets incorrectly, putting figures under the wron headings and sometimes reversing the correct sequence. Another example of his abnormal behaviour was that he went home and attempted to make a cup of coffee, but when the kettle boiled he carried it to the bathroom and poured it down the sink. He was aware that he was acting abnormally. He comments that he had to concentrate a great deal before performing a task which previously would have required very little thought.

At this stage he remembered that he had been unwell five years before, after taking tablets that had been prescribed for his patch of baldness. He therefore stopped the chloroquine, and during the following week he became quite well again. During the period he was taking chloroquine he did not notice any difficulty with his eyesight, and examination of the retina did no show any abnormality. $\mathrm{He}$ thinks that the chloroquine helped the alopecia.

The records of his treatment five years before at another hospital were obtained, and these showed that the tablets which upset him at that time were chloroquine and mepacrine. He only remembers that the tablets nauseated him when he took them at that time.

The Table summarizes this case and cases reported previously. It will be seen that with the exception of one case the dose of chloroquine taken before the signs of intolerance

Cases of Chloroquine Psychosis Published Previously and Present Case

\begin{tabular}{|c|c|c|c|c|c|c|c|}
\hline & Report & $\begin{array}{c}\begin{array}{c}\text { Form } \\
\text { of } \\
\text { Chloroquine }\end{array}\end{array}$ & $\begin{array}{c}\text { Condition } \\
\text { being } \\
\text { Treated }\end{array}$ & Dose & $\begin{array}{l}\text { Total } \\
\text { Dose }\end{array}$ & $\begin{array}{l}\text { Time } \\
\text { of } \\
\text { Onset }\end{array}$ & Mental State \\
\hline & $\begin{array}{l}\text { Present case } \\
\text { Sapp }^{4}\end{array}$ & Phosphate & $\begin{array}{l}\text { Discoid L.E. } \\
\text { Amoebic }\end{array}$ & $\begin{array}{l}250 \mathrm{mg} \text {. b.d. } \\
\text { Reducing to }\end{array}$ & $\begin{array}{l}5 \mathrm{~g} . \\
4 \%\end{array}$ & $\underset{6}{20}$ days & $\begin{array}{l}\text { ed state } \\
\text { on, }\end{array}$ \\
\hline 3 & $\mathbf{R a b}^{\circ}$ & Sulphate & $\begin{array}{l}\text { dysentery } \\
\text { Amoebic }\end{array}$ & $\begin{array}{l}250 \mathrm{mg} \text {.b.d. } \\
250 \mathrm{mg} \text {. q.i.d. }\end{array}$ & 6 " & $6 \%$ & $\begin{array}{l}\text { hallucinat } \\
\text { Confused, }\end{array}$ \\
\hline 4 & - & " & & 250 & $6 "$ & 6 " & $\begin{array}{l}\text { violent } \\
\text { Confused, }\end{array}$ \\
\hline 5 & Dubois? $\quad .$. & - & Systemic L.E. & 0.5 g. daily & - & - & Personality \\
\hline 6 & Burrel1 $^{8}$ & - & Cardiac & 1 g. daily & - & - & Psychosis \\
\hline 7 & Mustakallio ${ }^{\ominus}$ & - & $\begin{array}{l}\text { arrny } \\
\text { Solar }\end{array}$ & & $4.7 \mathrm{~g}$. & 40 days & Depersonaliza- \\
\hline 8 & $\begin{array}{c}\text { Downhorst \& } \\
\text { Robinson }^{10}\end{array}$ & Sulphate & $\begin{array}{l}\text { Rheumatoid } \\
\text { arthritis }\end{array}$ & $\begin{array}{l}\text { Daily } \\
600 \mathrm{mg} .\end{array}$ & $2 \cdot 4 "$ & 4 " & $\begin{array}{l}\text { Agitated, con- } \\
\text { fused, deluded }\end{array}$ \\
\hline
\end{tabular}

developed was about $4 \mathrm{~g}$. This form of intolerance to chloroquine seems rare, though it is notable that over 300 cases of psychosis attributed to the related drug mepacrine have been reported.

All the patients had similar symptoms, becoming confused and agitated, but with some insight into their condition in the early stages. All recovered after stopping the drug, usually after a period of about a week. Apart from stopping the drug and giving sedation the other treatment which has been suggested is the acidification of the urine as this increases urinary excretion.

I wish to thank Dr. M. Garretts and Dr. J. M. M. Young for their assistance with this report.

-I am, etc.,

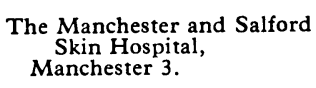

Manchester 3.

D. B. Brookes.

REFERENCES

Prokoptchouk, A. J., Zbl. Haut- u. Geschl.-Kr. 1940, 66, 112.

2 Page, F., Lancet, 1951, 2, 755.

3erwin, C. F., and Winkelmann, R. K., Mayo Clin. Proc., 1962, 37, 253.

Sapp, O. L., F. Amer. med. Ass., 1964, 187, 373. Grünfeld, R. L., Arch. Derm. Syph. (Chic.) $1909,95,331$

Rab, S. M., Brit. med. F., 1963, 1, 1275

Dubois, E. L., Ann. intern. Med., 1956, 45, 163 L, jun and Martinez, A, Ner Engl. F. Med., 1958, 258, 798.

- Mustakallio, K. K., Putkonen, T., and Pihkanen T. A., Lancet, 1962, 2, 1387. Dornhorst, A. C., and Robinson, B. F., ibid. $1963,1,108$.

\section{Pain in the Neck and Arm}

SIR,-We read with great interest the paper "Pain in the Neck and Arm: Multicentric Trial of Physiotherapy" (29 January, p. 253). It is gratifying to note that the effects of various forms of treatment and placebo are more or less identical, and that postural correction with assurance from the physiotherapist was found to be very helpful. There has been, however, no attempt to pinpoint the diagnosis. It appears that the cases selected for treatment included cervical spondylosis, myelopathies, root compression from foraminal encroachment, and costoclavicular compression without any radiological abnormality ; neck pain being present in all.

A good number of such cases in our experience have been found to be due to fibrositis, with clinically palpable tender nodules in different planes of the muscles suspending the girdle. These cases are cured, even in presence of gross degenerative change in the cervical spine or of a cervical rib, when the nodules are treated with local infiltration, heat, deep massage, short-wave diathermy, ultrasonic therapy, etc., followed by intensive girdle muscle exercises. The last obviously helps to correct the posture of the girdle. None of these cases required cervical traction or a collar.

This leads to the question whether the brachial neuropathy could be secondary to girdle drop due to atrophy and power insufficiency of the muscles from pain. Should not these cases be labelled as fibrositis with secondary costoclavicular compression? -We are, etc.,

Nil Ratan Sirkar Medical College, Calcutta.

Institute of Child Health, Calcutta.
A. K. SAHA

A. Sengupta. 